\title{
Recombinant Interferon Alfa-1b
}

National Cancer Institute

\section{Source}

National Cancer Institute. Recombinant Interferon Alfa-1b. NCI Thesaurus. Code C53411.

The non-glycosylated recombinant interferon alpha, subtype $1 \mathrm{~b}$, with immunostimulatory and antineoplastic activities. Alpha interferon-1 $\mathrm{b}$ binds to specific cell-surface receptors, resulting in the transcription and translation of genes whose protein products mediate antiviral, antiproliferative, anticancer, and immune-modulating effects. 